\title{
State Responses to Victims of Terrorism Needs in Spain Javier Argomaniz
}

\section{Introduction}

Spain currently has one of the most advanced systems of support for victims of terrorism. Undoubtedly, this is explained by the long prevalence of political violence in the country: the longest-running terrorist organisation in Europe Euzkadi Ta Askatasuna (ETA) is active since the 1960s and -albeit currently holding a permanent ceasefire- still operates. The degree and multiplicity of the violence is also an important factor: thousands of Spanish citizens have been targeted by armed groups operating at both poles of the ideological spectrum (extremeleft and extreme-right), separatist organisations, jihadist networks, operatives working for international terror groups and by state actors.

The legacy of more than four decades of violence has encouraged the authorities to protect the rights of a community whose numbers are, sadly, very large. Thus, a growing realisation of the extent of the problem, coupled with the avid activism of victims groups, has resulted in a process whereby the authorities have gradually come to understand the complexity and the diversity of the needs of the victims. The Spanish framework of support evolved slowly at first, then much more rapidly in recent times but, overall, victims have had a long and continuous struggle to achieve the support and recognition they now experience. 
Historically, state protection of victims of terrorism was non-existent: in the 1970s support was very limited and it remained so during the 1980s with some exceptions for state officials. This statutory neglect of the victims of terrorism at this time was exceptionally unfortunate as in the transition from the Franco dictatorship to a parliamentary democracy in the late 1970s terrorist activity was a frequent occurrence in Spanish and particularly Basque society. During this period of transition, political instability was at its peak. Hardliners from the previous regime were disgruntled with the pace and nature of reform -there was even a serious coup attempt on 23 February 1981- and a wide variety of militant organisations were involved in conducting campaigns of violence and subterfuge (Shabad and Llera, 1995). This period was ETA's bloodiest phase but they were not alone in their violent actions (SánchezCuenca, 2007; Reinares, 2003). Terrorism was also being conducted, albeit to a much lesser extent, by other ethno-nationalist organisations (i.e. the Catalan Terra Lliure), the extreme left (GRAPO-First of October Anti-Fascist Resistance Groups) or the extreme right wing (i.e. Batallón Vasco Español).

The fallout of this terrorist violence was felt most acutely by the victims and their families. A failure to secure any institutional support let the victims themselves to act in their own interest. Given that the government of the period was more anxious to contain the wave of paramilitary violence and failed to address the impact on the victims, around this time the formation of the first victims support groups occurred with the intention to act in a self help capacity. Currently largest Spanish victims' association, the Asociación de Victimas del Terrorismo (AVT), emerged in this manner and was established in 1981 to try to fill and lobby against the significant gap in statutory support; a considerable challenge, given their then limited resources. 
Due perhaps to the actions of volunteer organisations and the mounting number of victims of terrorism, during the 1980 s the first steps were taken by public authorities to address the lack of statutory provisions for victims of terrorism. This move occurred during a time when the phenomenon of terrorism became monopolised by the actions of ETA, and a progressive institutionalisation and strengthening of the democratic regime was underway.

However, it was not until the late 1990s that it could be reasonably said that Spain had a comprehensive support system in place for victims. By then, ETA, though still capable of high-profile attacks and sustained short-term campaigns, had been greatly weakened but left a legacy of death and destruction in its wake. Sustained progress came often as a response to the demands put forward in public by victims. Importantly for the advancing of the victim cause, the mobilisation of peace groups, civic movements and victim organisations in Basque Country became especially visible during this time (Funes, 1998; Martínez Gorriarán, 2008).

While the landscape of terrorist victimisation in Spain is dominated by ETA violence, the dramatic jihadist attacks of 11 March 2004 refocused both public and political attention on terrorism and resulted in the increased prioritisation of victims needs by the authorities. In particular, the emergence of two new victims groups ${ }^{1}$ created to protect the rights of the large number of people affected by the bombings assisted this refocusing. ${ }^{2}$

The result of these efforts over the last two decades is a complex institutionalised system of support for victims of terrorism operated by a number of statutory bodies and legislative 
initiatives at both the state and regional level. ${ }^{3}$ These institutions not only directly deliver services but also maintain a political purpose in that they act as intermediaries between the victims' community and the Government.

Given the long and complex history of terrorist victimisation in Spain, it is the aim of this chapter to provide an overview of both the legislative regimes and the existing institutional entities set up in Spain and Basque Country in response to the decades of violence. It will not only describe the current system but also explain its evolution. In doing so, the chapter will examine those aspects of the victims' experience largely addressed by public bodies and also those that, according to victims representatives, are yet to be met. The main argument presented here is that the individual needs of the victims are presently relatively well-covered in terms of the legislative measures in place, yet the public dimension of victimhood requires further efforts and, in fact, it may not even be necessarily possible for the central government to fully guarantee every public right requested by victims groups.

\section{Statutory bodies}

Whereas victims support legislation began being introduced in the early $1980 \mathrm{~s}$, limited as it was, the establishment of the first statutory bodies did not occur until much later. During the 1990s, as a reflection of the shift from a purely compensatory stance to a more inclusive and exhaustive provision of welfare care, statutory bodies began to emerge. This first stage was followed by a second phase when progressive expansion of state assistance led to the enhancement and strengthening of these institutions during the 2000s. 
Their remit is to assist victims from terrorist acts, which in the Spanish legal are understood as:

Acts carried out by members of organisations or criminal groups whose aim is to subvert the constitutional order or seriously disturb the public peace.

[and] acts carried out to achieve the objectives described in the above paragraph, even if the perpetrators are not members of such organisations or criminal groups. ${ }^{4}$

Current legislation defines victims as: those deceased or having suffered physical or psychological harm as a result of terrorist acts; persons with family ties, cohabitation or dependency relationship with the deceased; and individuals having suffered material damage from the act. In addition, family members of the deceased up to second degree of consanguinity and those who, despite being targets, were unhurt, are also considered victims for the purposes of public and individual honours (with no right to compensation, however). ${ }^{5}$

The overall institutional structure of support is not overly complex. Within central government, financial compensation is processed by a General Directorate for the Support of Victims of Terrorism in the Spanish Ministry of Interior. They are assisted by the Victims of Terrorism Foundation (FVT), which is a public agency set up in 2002 that coordinates the work of victims groups in Spain. In addition, other Ministries have initiated actions that are also relevant to claims made by victims' organisations. Finally, within the Basque government there exists the Directorate of Care to Victims of Terrorism providing an added layer of support for Basque victims. 
The General Directorate is the primary actor in the field of Victim Support. It was initially preceded by the General Subdirectorate of Citizens Service and Victims of Terrorism Assistance established within the Ministry of Interior in 1996. Essentially the Sub-directorate was initially tasked with providing information for the victims of terrorism regarding their rights under existing legislation and also developing social programmes for their benefit.

More specifically, the three main objectives for the Subdirectorate were to:

1) Provide integral assistance to victims.

This was achieved by staff members establishing personal contact with victims at an early stage to provide support and then assist with their application for existing services. In addition, they would ensure the continuation of support for all victims.

2) Enhance public service delivery.

The Subdrectorate took charge of implementing the new benefits that the 1996 Law introduced: educational grants, psychological and psycho pedagogical treatment, financial compensation and the public funding of victims organisations.

3) Develop new schemes to better understand and improve the welfare of victims. This involved the setting up of links with victims organisations in order to provide effective and accurate information via these groups, receive feedback and improve existing reparation schemes (Pulgar 2004). 
It must be noted however that the unit itself did not have a managerial function. The Subdirectorate served mainly as an intermediary, helping to coordinate the work of different parts of the administration, channelling resources and ensuring that other ministries and departments would put in place the required instruments.

All in all, the creation of this Subdirectorate made a significant and positive difference to the relationship between the institutions and the individual victims and their families. For the first time there was a functioning body liaising between the individual and the authorities that could provide an effective follow-up and directly respond to existing issues. The presence of a contact point and a permanent team of staff to discuss face-to-face, these matters helped many families to feel, unlike those victimised in the 1970s and the 1980s, a real sense of solidarity with their plight (Pulgar, 2004). Most importantly, the creation of this unit also allowed state authorities to obtain a better understanding of the personal needs of the victims of terrorism.

In addition to this unit, the post of High Commissioner for the Support of Victims of Terrorism also merits attention. The office was created in 2004 by the Spanish government, and the reputed Spanish jurist Gregorio Peces-Barba was appointed to the role in. In the two years during which Perez-Barba held the post, he worked closely with the Subdirectorate to advance some of the existing schemes, particularly those aiming at extending assistance to those persons who were yet to receive remuneration. ${ }^{6}$ However, the fraught relationship between the Commissioner and the leadership of the largest victim group, the AVT, motivated the government's decision to eventually abolish the position following PerezBarba's resignation. $^{7}$ 
As a result, in 2006 both the High Commission and the sub-directorate became subsumed in a General Directorate. Such reorganisation was widely regarded within government as a necessary step to facilitate the expansion of the system: since it was better resourced and higher ranked, this new Unit would in theory be better prepared to manage the tripling of subsidies that occurred in the 2000s from the previous levels in the 1990s.

Soon after the establishment of this new bureaucratic structure, a number of ambitious schemes were put in place. For instance, a high profile programme for the detection and recognition of victimised individuals was established in 2006. Its goal was to identify those direct victims (survivors, widows and orphans) who were yet to be informed of their rights due to the fact that they did not originally join the legal proceedings. Staff from the Unit studied more than 800 court cases and - often following a long and complex process- located about 300 victims who then received compensation (Rodriguez Uribes, 2011).

In parallel to these initiatives, a home-based care programme was established to strengthen the direct contacts with victims and to ensure personalised attention. The scheme involves a team of social workers who intervene directly with and on behalf of victims following individual requests. They seek to mediate between the Directorate and the individual and liaise with local authorities to resolve existing problems that the individuals may be experiencing as a result of their victimisation. This represents a natural evolution from the original goals of the 1996 Subdirectorate: to bridge the gap between the victim and the institutions. 
There is also an international dimension to the provision of services for victims of terrorism; the Directorate has worked with organisations to set up schemes benefitting victims regionally (i.e. with the European Commission) and internationally, such as the promotion of the formation of new professionals in this field. It has also acted to amplify the voice of victims groups globally by supporting their participation in intergovernmental forums in order to generate awareness and contribute to the deligitimisation of terrorism. Hence, in a recent example, the Spanish Minister of Interior, in collaboration with Spanish victims groups, has been lobbying the European Commission for the approval of a Charter of Victims Rights. This ambitious document would lead to the creation of an international legal framework specifically related to the experiences of victims of terrorism and separate from those more general regimes concerning victims of violent crime (Ramos, 2013).

Victims of Terrorism Foundation (FVT)

As mentioned, complementing the work of the General Directorate, the Victims of Terrorism Foundation (FVT) acts as the other main statutory body. The FVT is a non-profit institution created in 2002 that is funded by both public institutions (national and regional governments) and private entities (mainly commercial foundations). Its board of trustees encompasses intellectuals, business leaders, representatives from victims groups and officials from the Ministries of Presidency, Interior, Finance and Education, Culture and Sports.

The organisation's statutes present a series of objectives that can be summarised into three main goals: to raise awareness domestically and in the international sphere about the status of 
victims of terrorism; collaborate with, fund and guide the work of victims organisations and, finally, initiate their own support programmes. ${ }^{8}$ In addition to directly funding victims organisations, the FVT has been an active promoter of activities, subsidising almost a hundred separate projects on average per year, the large majority of them run in conjunction with individual victims groups. Thus, in 2012, a number of innovations in terms of funding emerged; a program of conferences to be delivered in schools was developed seeking to delegitimise political violence, commemorative concerts were supported, outreach activities at the UN and EU were conducted, summer schools received, seminars, conferences and academic research was subsidised, support was offered for the organisation of commemorative awards, high-level meetings with representatives from victims organisations received assistance, as did judicial assistance schemes and psychological assistance programmes. ${ }^{9}$ The FVT does therefore play a fundamental role in promoting the rights of the community and actively seeks to ensure a coordinated action amongst the more than 30 foundations and organisations working in this area.

\section{Additional actors}

Despite the fact that the Directorate and the FVT are the focal points through which government's support is channelled, it goes without saying that other entities have also been involved in delivering support to victims of terrorism. As an illustration, the Ministry of Justice, in co-operation with the National High Court and victims associations, set up an online tool that allows individual victims to retrieve information related to their court proceedings (Ramos, 2013). This online platform adds to the work that the Office for Informing and Supporting Victim of Terrorism has been carrying out within the National 
High Court since 2006. The Office facilitates information about the judicial proceedings and enforcement of sentences, accompanies and attends victims during the trial and ensures their security and privacy.

Still within the judicial sphere, the Spanish government also decided to be party for the first time to court proceedings in a foreign country in response to ETA's murder of two Spanish Guardia Civil officers in Capbreton (France) in 2007 (Rodriguez Uribes, 2011). This is a highly symbolic move, mostly designed to show solidarity with the direct victims and the community as a whole.

Due to the nature of victim support, some schemes naturally require the cooperation of regional and/or local bodies. In recognition of this need, the Ministry of Interior is actively cooperating with the Basque Government to establish a Memorial Centre for Victims of Terrorism. ${ }^{10}$ Announced in the 2011 Law of Recognition and Comprehensive Protection for Victims of Terrorism, the Centre aims to 'preserve the democratic and ethical values embodied by the victims, build a collective memory and raise awareness regarding the protection of liberties and human rights' (BOE, 2011). It is expected to be built in VitoriaGasteiz, the administrative capital of Basque Country. This major scheme is being complemented by other memorialisation initiatives such as the Spanish Parliament decision to declare 27 June the Victims of Terrorism Day.

Finally, the central government's plans are complemented in Basque Country with the work carried out by the Directorate of Care to Victims of Terrorism. This administrative Unit is 
remarkable for being the only existing regional statutory body (although it must be noted that the Basque Parliament Presidency has also organised exhibitions, erected monuments and organised commemorative events). ${ }^{11}$ The Directorate replaced in 2002 the previous Office for Victims of Terrorism Assistance that had been set up in 1991 in order to provide closer and more personalised care to the victims. These tasks are presently conducted through written communication and, if required, individual meetings, where victims are informed of the existing programmes (Pérez, 2003). Staff members can also accompany them to their trials, which are generally carried out in Madrid. This is one of most positively received services (Varona, 2009). In addition, the Directorate facilitates the organisation of commemorative events and channels existing funds to local victims groups. Importantly the remit of this body included from the beginning efforts to assist citizens suffering from political persecution (violence by ETA support groups or individuals, extortion, blackmail and so on) thus effectively expanding the definition of victims of terrorism. As it will be shown below, this decision was adopted more than a decade before it became part of the national regime.

\section{Legislation}

There are a considerable number of legislative initiatives developed over the last forty years that have impacted upon the lives of victims of terrorism in Spain. Most of these legal texts are simple enhancements of existing statutes, developed to fill existing gaps, modernise levels of remuneration and clarify certain provisions. So, while accounting whenever possible for these minor efforts aimed at progressively refining the existing legal tools -and given the existing space limitations-, the following analysis will concentrate on the dominant legal instruments developed in support of victims of terrorism. 
The section will examine both State and Basque legislation. On this, it should be mentioned that the Basque Parliament is not the only regional legislative body that has acted in this area, others have produced their own schemes -Madrid and Navarre have been especially active-. In legal terms, regional programmes are seen as complementary and subsidiary to national ones, yet the Basque Country deserves special attention due to the obvious fact that it hosts the most active and dominant terrorist group in the country and, as a result, also a majority of terrorism victims. Furthermore, and in response to this long history of violence, successive Basque governments have developed some of the most progressive legislation in this area.

\section{Spanish legislation}

As noted in the introduction, the early victims of terrorist attacks occurring in the transition to democracy in the 1970's received no formal assistance from state authorities. The first limited attempt at offering victims restitution can be found in Article 7 of the 1979 Legislative Royal Decree on the Protection of Citizens' Security. This legislation included for the first time the possibility of State compensation for physical damages derived from terrorist acts (BOE, 1979). Following from this initial step, a series of initiatives gradually improved the remuneration provided by the state, most relevantly the 1984 Organic Law against the activities of armed groups and terrorist organisations (BOE, 1984). While these and other legal measures of the period ${ }^{12}$ were welcomed, oftentimes the assistance was insufficient to return the families and the victims to the economic standards they enjoyed previous to the attack; in effect they did not compensate entirely for the impact of the incident. 
These series of legal mechanisms mostly served to produce minor amendments to the amounts destined for financial compensation through the vehicle of extraordinary pensions for public workers. Furthermore, up until the 1990s, the framework evolves in an uncoordinated manner, producing a convoluted structure that resulted in involuntary processes of preferential treatment towards certain categories of victims.

For instance, with the application of the 1987 Legislative Royal decree on Civil Service Pension Funds, the extraordinary pensions regime is improved, raising the amounts for military officers and/or civil servants who fell victim of terrorist attacks Yet this was discriminatory towards public workers victimised before the passing of the law and the disparity could be as substantial as hundreds of euros per month.

Equally important, substantial financial support remained restricted to state workers. The rationale behind this decision is that, during the 1970s and 1980s, the majority of the victims were members of the state security and armed forces. Yet this position became increasingly problematic as the number of civilian victims continued growing.

These glaring gaps encouraged further pressure by victims on the government to reform and streamline the system to ensure a wide and fair provision. In the late 1980s the system of extraordinary pensions was finally extended to any citizen injured in an attack but the necessary process of rationalisation did not actually materialise until the 1990s, mainly following the 1992 Royal Decree to regulate compensation for damages to victims from armed bands and terrorist elements (BOE, 1992), the 1996 Law on fiscal, administrative and 
social order measures (BOE, 1996) and the 1997 Royal Decree Regulation of assistance and restitution for victims of terrorism offences (BOE, 1997). These measures included compensation for both material and personal damages resulting from terrorist attacks carried out after the passing of the law. So these legal texts not only improved financial support for survivors and relatives of the deceased but also introduced subsidies for the reparation of homes, businesses and vehicles damaged by terrorist incidents. Importantly, state support is broadened to include, for the first time, funding for medical and psychological treatment. As part of this expansion, psycho-pedagogical and educational support could be offered to students.

The combined effect of these legal texts resulted in the widening of the coverage to certain groups within the victims community and a renewed effort to solve the discriminatory practices resulting from the unsystematic formulation of legal reforms during the $1980 \mathrm{~s}$ (Pulgar 2004). Such aspirations become solidified in the 1999 Law of Solidarity with Victims of Terrorism. The 1999 Law became the first Spanish legal text to exclusively focus on the victims since previous relevant measures had always been part of broader finance or antiterrorism acts. Importantly, the legal text received unanimous support in the Spanish Congress: it was passed in record time and none of the parliamentary groups tabled any amendments to the proposal (Mir Puigpelat, 2000b). This is a reflection of the existing political context: ETA had declared a ceasefire in $1998^{13}$ and, by compensating the victims, the legislation was seen as a step forward in the transition to a post-conflict scenario (Lloveras, 2002). 
The 1999 Law brought about a series of major innovations. Foremost is the fact that abovementioned benefits were extended retroactively to the victims from the previous three decades starting from 1968 (BOE, 1999). Undoubtedly, the retroactivity of the Law has major implications. Firstly, it seeks to prevent the emergence of the inequalities in treatment and instances of discrimination that had plagued the application of the law in previous years. Secondly, and in what became a highly symbolic move, it implied the extension of state support to victims of those instances of political violence that had occurred previous to the establishment of the democratic system.

This decision served to provide restitution to those harmed in the first terrorist attacks ever carried out by ETA but it did not come without costs. Since in 1968 Spain was still under Franco's dictatorship, it explicitly undermines the idea frequently found in the official discourse that victims are targeted in order to erode the constitutional and democratic order. As an illustration, the 1999 Law states that support for the victims 'constitutes a point of agreement for all democrats' (BOE, 1999: 36050). Moreover, in a more recent legislation, it is described how 'victims of terrorism are also an ethical reference point for our democratic system. They symbolize the defence of freedom and Rule of Law in the face of the terrorist threat' (BOE, 2011: 100566). Therefore, in an attempt to ensure wider coverage, the 1999 Law erodes the internal coherence of the narrative tying the suffering of the victims with the defence of democratic values.

Likewise, following the need to ensure fairness, the legislators designed a parallel compensatory arrangement for those victims affected by an attack whose authorship had not been clarified by the courts. Continuing with the existing approach, minimum levels of 
remuneration were assigned and these varied depending on the type of harm suffered: death, different degrees of disability or abduction. Also following previous trends, the amounts were increased substantially.

Another important novelty is that the 1999 Law gave the right to those harmed by terrorist attacks to, following the general rules of tort law, be compensated by the State. Public authorities would become responsible for compensating the victims in those cases when individuals convicted for violent crimes would not possess the funds to pay damages. Essentially, this duty is assumed by the state following the principle of solidarity and it is actually stressed out that this does not entail state's acceptance of subsidiary liability from every terrorist act (Martín Ríos, 2008; Lloveras, 2002; Mir Puigpelat, 2000a). So, as Lloveras (2002: 14) argues, more than compensations, these payments can be better described as public subsidies.

These major innovations were also accompanied by some minor reforms: it is noticeable that the legislation enacted the exemption of academic fees for victims and direct relatives substituting the previous individual agreements with universities. It also led to some initial steps towards symbolic reparation with the creation of the new honorary distinction Real Orden de Reconocimiento Civil a Las Victimas del Terrorismo, which involves two distinctive awards: the Gran Cruz -in case of murder- and the Encomienda -for those injured and/or kidnapped by armed groups-. ${ }^{14}$ 
Due to all these important advances, the 1999 Law laid out the foundation for the current regime of victims' support and regulated, with some minor amendments, the assistance to victims for more than a decade, when it was finally superseded by the 2011 Law of Recognition and Comprehensive Protection for Victims of Terrorism.

The introduction of this new legislation came as a result of the partial failure of the 1999 Law to eliminate disparities. More specifically, victims of attacks whose perpetrators had not been charged nor convicted, even if now entitled to monetary payments, would still receive lower amounts than other members of the same community. This was due to the fact that there had been judicial sentences where the courts had awarded more generous levels of compensation than those detailed in the 1999 Law. Pressure by victims organisations, who continued being critical of instances of differential treatment and the over-complexity of the legal framework, led to a revision of the existing legal arrangements. Thus, in a 2007 declaration, a number of associations raised a series of important issues requiring government action. These included inter alia the stringent time limits present when applying for state support, the necessity to simplify these processes, the narrowness of the legal definition of 'victim of terrorism', the imbalances created by the existence or absence of a conviction, the need to personalise psychological treatment and the absence of support for people threatened and coerced by ETA-support networks. ${ }^{15}$ The document served to coalesce the views of victims' organisations and to more effectively influence the shaping of the legislation. Eventually a number of those demands were finally met by the 2011 Law.

This recent legislation has allowed victims to apply for state assistance resulting from attacks occurred from 1 January 1960, extending the existing time span 8 more years. The choice of 
this particular year is far from arbitrary. It meant that the law covers the death of Begoña Urroz, who was less than one year old when hit by a bomb planted in a train station in the Basque city of San Sebastian (Alonso, Dominguez, Garcia Rey, 2010: 16). She is considered by some experts to be the first victim of ETA, although this interpretation is strongly disputed by other historians, who point the finger instead at another armed group, the short-lived, DRIL (Directorio Revolucionario Ibérico de Liberación). ${ }^{16}$ The implicit connotations regarding the question of the identity of the perpetrators are evident and do not require further elaboration but, either way, what it is incontestable is that this was an act of terror.

The 2011 Law has continued and reinforced the pattern towards the deepening and broadening of support. On the one hand, it streamlined and increased financial assistance and extended the provision of first aid and psychological assistance, including specialised training for medical professionals. On the other hand, for the first time, compensation was extended to nationals victims of terrorist acts that occurred abroad, addressing in this way one of the gaps of the 1999 Law, which did not specify the territorial scope of application (Mir Puigpelat, 2000a).

Most important is the fact that the legislation explicitly formalises a new principle of 'integral assistance', which is basically a holistic approach to victims' support. This perspective embraces the provision of multi-dimensional educational, medical, psychological and financial assistance, and recognises that full reparation goes further than simple financial assistance. In practice, the 'integral assistance' principle constitutes more evolutionary progress than a radical transformation, essentially because this norm was already governing action in this area since the late 1990s. So what this does is to offer some continuity in the 
more comprehensive approach delivered by the 1999 Law. At the same time, the key innovation is that the 2011 version of the 'integral assistance' principle now incorporates the notion, already present in the Basque legislative regime-as we will see-, of the public and social dimensions of victimhood.

Hence, in recognition of the public dimension of victimhood for the victims of terrorism, the 2011 Law of Recognition developed a number of instruments to protect and respect the dignity of victims in the public sphere. These include the formulation of media guidelines to avoid any disproportionate or inadequate use of images of victims and a ban on advertising that may treat them disrespectfully individually or as a group. At the same time the Law prohibits the public glorification of terrorism ${ }^{17}$ with the aim of preventing instances of revictimisation.

Furthermore, it also states that public authorities must set up active measures to ensure maximum respect for victims through the use of symbols, the erection of monuments, and other institutional acts. The 2011 legislation also calls for the promotion and commemoration of the memory of victims of terrorism.

Most recently, on 6 September the 2013 Regulation of the Law has been finally passed by the Spanish parliament. On the one hand, its approval has evidently suffered from long delays that have been heavily criticised by victims associations. ${ }^{18}$ On the other hand, the lengthy decision-making has facilitated the inclusion of additional demands made by representatives from victims groups in meetings with government officials (FVT, 2013). 
Undoubtedly, the most important contribution of the 2013 Regulation is that, for the first time, victims of politically-motivated harassment and persecution can receive state's assistance in a number of areas. ${ }^{19}$ These include help moving to another property or location, psychological treatment, job placement, exemption of school fees and others. This is especially important for citizens living in those locations in Basque Country where nonnationalist public figures (journalists, civil servants, local councillors, regional politicians, businessmen, intellectuals, academics and others) have personally suffered for years the effects of the so-called Kale Borroka ('street fighting', also described as 'low-intensity terrorism'). These acts of individual and group intimidation have included inter alia insults, death threats, extortion, beatings and the targeting with incendiary artefacts of their homes and personal property (see Martin-Peña et al. in this volume). Many had been forced to abandon Basque Country due to these forms or persecution (Calleja, 2006). These forms of violence are these days much less prevalent, following ETAs permanent ceasefire and the Abertzale Left's ${ }^{20}$ progressive shift towards the exclusive use of political means, so the numbers of current potential beneficiaries are much lower than in the recent past. Yet because the regulation is retroactive until 1 January 1960, this assistance can serve as a form of restitution for those who have suffered in the past very severe and stressful forms of psychological and physical violence.

The 2013 text also increases the amounts for medical and psychological treatment as well as housing, labour and educational assistance (BOE, 2013). Thus, the limit for the psychological treatment of victims, persecuted individuals and their close family has been raised from 3,000 to $6,000 €$. Educational grants now range from 300 to $1,500 €$ and victims' children studying at primary and secondary education levels can receive free psycho pedagogical support if 
required. Prostheses and surgical operations not covered by the national health system or private medical insurance will continue being subsidised by the State.

The amounts available have also increased for those cases when the person's property (from 90.000 to $113.680 €)$ or vehicle/s (21.035 to $30.500 €)$ have suffered from structural damage as a result of a terrorist bombing. Victims do also receive expenses for the costs derived from temporary accommodation resulting from the attack ( $90 €$ per person and night in a hotel and $1,500 €$ for monthly rent). Importantly, the buildings of NGOs, political parties and trade unions, frequent previous targets of the Kale Borroka, are also included in the scheme (reparations for damages increase from 21.035 to $30.500 €$ ).

Finally, victims have had their labour rights strengthened by becoming a priority group in the State's employment policies and through the prospective signing by the Government of agreements with companies to facilitate their employment. Given the current economic climate, with a national average unemployment rate of about $26 \%$, this is seen as an especially important need since some victims have had to leave their previous jobs due to the temporary or permanent physical and psychological disability caused by the injuries.

The new Regulation gives the Spanish Minister of Interior full competency over the support of victims since some elements were previously shared with other ministries, including studentships and grants (Education) and civilian and military honours and awards (Ministry of the Presidency). In theory, this will facilitate the provision of state assistance as victims would only need to process their claims through one single institution (Ramos, 2013). 
All in all, the main contribution of the 2011 Law and the 2013 Regulation has been that they addressed the problem of the increasing complexity and intricacy of the system, with a growing body of laws that had been developed rather convolutedly in waves for three decades. Hence, by fusing in a single legal framework all previous advances, the two instruments have considerably simplified and streamlined the existing support system.

Finally, there have been more limited proposals in this period that have aimed to assist the victims' collective. For instance, victims of terrorisms were one of the groups (victims of domestic abuse, etc.) who became exempted from paying fees in their legal proceedings when the Spanish government introduced a controversial legal reform. ${ }^{21}$ Victims of terrorism are also one of the groups who have preferential access to social housing as specified in the 2013 Royal Decree on the promotion of property letting, rehabilitation of buildings and urban regeneration (BOE, 2013).

In addition, other legislative initiatives, even if they do not they directly address victim rights, respond to long-running demands by victims' organisations. Most relevantly, with the passing of Organic Law 5/2010 reforming the Spanish penal code, serious terrorist offences do not have a statute of limitations. To be precise, Article 131 of the reformed code states that, provided they have caused death, terrorism offences shall not have a statute of limitations (BOE, 2010). This is highly relevant to both the public and individual dimensions to the victims' claim to justice, as described in the section below.

\section{Basque legislation}


As the Basque Country has been the region in Spain more heavily affected by political violence, successive Basque administrations have legislated on the issue of victims of terrorism for many years. The schemes that emerged in the region were the first in the country to embrace the previously neglected group of victims of political persecution and have brought to the fore the importance of the public character of victims' needs. Some of these dimensions have been later incorporated into national legislation but still not to a comparable degree. Therefore, due to the tragic experience of decades of terrorism, the region has become a policy laboratory for the development of inclusive and wide-ranging responses to the needs of the victims.

The first major initiative introduced by the Basque regional government was the 1988 Decree on The Programme of Assistance to Victims of Terrorism following a non-legislative motion passed in 1987 by the Basque Parliament Human Rights Committee (BOPV, 1988). This plan did undergo a series of changes in 1991, 1993, 1995 and 2000 before a majority of Basque MPs supported a proposal for the evaluation and -if necessary- improvement of the existing scheme in a number of areas: education, labour, housing, medical and psychological assistance.

In order to fulfil this requirement and, in addition to the creation of the Directorate of Care to Victims of Terrorism, a 2002 Decree by the Basque Parliament reformed the scheme to introduce new provisions and 'significantly improve' the levels of support for those who have suffered terrorist violence in Basque Country, regardless of their place of origin (BOPV, 2013). The Law introduces new plans to facilitate the employment of victims in both the 
public and the private sector, compensation for damages in property, improves educational support and enhances, more broadly, remuneration levels.

In the years that followed the implementation of this legislation, both the Basque government and the Basque parliament delivered a number of significant non-legislative measures. The former agreed in 2 May 2006 to the so-called Peace and Coexistence Plan ${ }^{22}$ and in 2007 to the Basque Plan for Education for Peace and Human Rights (2008-2011) ${ }^{23}$. These were a set of all-encompassing political agreements that focused on the defence of human rights, memorialisation and the pre-emption of violence, which also embraced victim rights and considered recounting victimhood experiences as a mechanism for promoting peace.

However, the 2006 document failed to attract the support of majority of the associations, who also criticised the 2007 Plan for failing to acknowledge their requests (Varona, 2009: 111112). On the other hand, when the Basque parliament passed a number of non-binding resolutions during this period calling for measures to alleviate the situation of the victims in the region, they were generally received more positively by supporters of their rights.

Overall, however, the 2008 Basque Government Law on Recognition and Reparation for Victims of Terrorism and its 2010 Regulation still remain the most important mechanism addressing victims' needs in Basque Country. A number of features make the 2008 Law a remarkable text. For a start, it follows the principle of flexibility so as to favour its beneficiaries in a number of ways. Firstly, it follows a pragmatic definition of the term 'victims of terrorism' -it does not require the acts being committed by an organisation, for instance- in order to facilitate the inclusion of the largest number of cases (Varona, 2009). Secondly, the legislation applies not only to those affected by incidents occurred within 
Basque Country but also to those cases abroad where Basque residents are affected (although this would not give the person access to all forms of assistance).

Moreover, it is noteworthy the strong influence of international human rights law, a factor explicitly recognised by the legislators. This is important in two ways: firstly, it implies a formal acknowledgement of the existence in Basque country of decades of serious human rights violations. Secondly, human rights law serves as the original source for the application to the Basque context of a series of previously unrecognised rights: Justice, Dignity, Reparation and Participation for the victim in Chapter I; Truth and Memory for victims and society (Chapter II); and Peace, Freedom and Coexistence for all Basque citizens (Chapter III) (BOPV, 2008).

The salience of these principles requires further elaboration. For a start, it can be argued that although these principles could be conceptually separated, in practice they are closely linked. The right of Participation, for instance, can be regarded as a mechanism to guarantee all other rights since it can be assumed that giving a say to the victims in the decision making process would mean that government measures are more likely to acknowledge and promote other public rights. On this, the 2008 Law follows existing international practices when calling in article 6 for the active participation of representatives from the victims' community in the elaboration of public policies aimed at this group. To accomplish this, a Victims of Terrorism Participation Council was established involving public officials and representatives from victims and peace associations in the formulation of policy proposals. ${ }^{24}$ 
Participation cannot be then fully understood without the right to Reparation, since the former exists to facilitate the latter. According to this notion, advanced through article 5, government policies should seek to bring the victim closer to his/her condition previous to the attack in all relevant spheres in life: personal, social and political (BOPV, 2008:17324). Reparation should also not only be for the individual alone but also the whole Community. This would be pursued through acts of memorialisation that reinforce and transmit a spirit of solidarity: ceremonies, testimonies, monuments and other symbolic expressions.

All these are described as acts to restore Dignity, a notion further discussed in article 4 . The protection of the Dignity of the victims is approached in the same way as in the 2011 Law of Recognition: through the training of professionals dealing directly with them, the protection of their privacy from media intrusion, and prohibiting public events that humiliate or treat victims and/or their relatives with contempt, glorify terrorist acts or pay homage to members of terrorist groups.

There is little doubt that the latter is the most problematic aspect of this legislation due to the fact that victims' associations have repeatedly criticised the absence of its effective implementation. In this way, the FVT has presented extensive evidence for the fact that acts that extol terrorism continue being organised in parts of Basque Country with impunity and that an appropriate judicial response is lacking. ${ }^{25}$ This represents a serious challenge for public authorities since the hostile attitude towards this provision by some local councils governed by independentist parties makes difficult the complete enforcement of the law. 
At the same time, the right to Justice is also widely seen as a fundamental priority by these organisations and, like most of these rights, has both a personal and a social dimension. Article 3 refers uniquely to the former dimension, it essentially concentrates on procedural law: victimised individuals will be better informed of the evolution of their case, have the option to be accompanied by officials to trials and measures will be put in place to protect their dignity and privacy during their participation in the trial. A wider understanding of the right held by victims' leaders also sees Justice as radically opposed to impunity, a guarantee that the state would do everything in its power to bring the perpetrators to justice and that those found guilty in court would serve their full sentence, which would discard any form of amnesty. ${ }^{26}$ However, since this is a core element in the state's counter-terror strategy -and therefore not a full competence of the Basque government- the 2008 Law avoids addressing the legal ramifications born out of this interpretation.

Chapter II covers two other principles with a long tradition in international law whose recipients are both the victims' community and society as a whole: Memory and Truth. As pointed out earlier, collective Memory is a fundamental mechanism to achieve Reparation: it serves to remind society of the fundamental injustices suffered by innocent citizens who experienced the violence. In the process, it reinforces the political meaning of victimhood. Thus, according to the text:

The right to Memory will contain as an essential element the political significance of terrorism victims, translated into the defence of all that terrorism seeks to eliminate in order to impose its totalitarian and exclusionary project: the liberties embodied in the democratic state, the rule of law and the right of the citizens to harmonious coexistence ${ }^{27}$ (BOPV, 2008:17325). 
Public Memory is also an instrument expected to de-legitimise terrorism by keeping the history of the period alive. Hence, effective Memory requires Truth, the accurate representation of the circumstances surrounding the acts of violence. This is seen to be achieved through the right of Participation, by promoting access to the official archives to assist in the protection of victims' rights and the development of historical research, and by supporting the identification of victims when their identities and/or whereabouts are unclear or -in case of confirmed murders- the location of the burial place.

Finally, Chapter III of the text enshrines Peace, Freedom and Coexistence as a fundamental set of related rights for all Basque citizens. It explicitly repudiates the use of political violence under any circumstance or ideology and the authorities commit themselves to protect the right of Basque citizens to live in 'peace and freedom, without violence, oppression or intimidation' (BOPV, 2008:17326). The government will also foster the dissemination of peace and democratic values through the education system (including the participation and reporting of victims' testimonies), promote active measures to delegitimise terrorism and prevent the use by individuals of Basque public radio and television channels to promulgate violence.

As established earlier, the inclusion of this comprehensive catalogue of rights represents a fundamental advance, one pursued by victims' groups for some time. It offers final acknowledgement that full reparation should occur both in the individual and the public spheres, the latter being especially important for the older victims, for whom solidarity and recognition eluded for years. 


\section{Conclusion}

In sum, the Spanish and Basque governments, as a response to public campaigning by victims of terrorism groups, have tried to meet the needs of victims by creating specific statutory bodies and particular legislation. The result is top-down structured, highly developed and institutionalised arrangement. Although Spain has presently developed one of the most advanced national legislations in the field, the current victims' support framework took more than four decades to emerge. During the transition period to a democratic regime in the 1970 s political violence of every ideological persuasion was prevalent but victims of such violence received no noticeable institutional support. It was in the mid-1980s, once democracy was effectively consolidated, when the first timid attempts at improving the welfare of the victims are carried out. These measures were at first limited to specific categories of victims but the scope of the financial assistance gradually broadened through the emergence of new laws on extraordinary pensions for victims that were passed in the late 1980s and early 1990s. With the 1999 Law of Solidarity, the first major piece of legislation in this area was approved. The 1999 Law constituted a major step forward, even if it is still mostly focused on remunerative aspects.

In the following years the institutional framework of support strengthened: the Victims of Terrorism Foundation was established in 2002, the General Directorate for the Support of Victims of Terrorism evolved from the merging of pre-existing institutional actors in 2006 and in 2002 the Basque Directorate for Care to Victims of Terrorism emerged. This evolution occurred alongside the growth of the civil society victims groups especially following the 11 March jihadist attacks in Madrid. 
Most importantly, the rights of the victims of terrorism were extended as part of the establishment of the principle of 'integral support', which represents both the recognition by state authorities that full reparation for the victim involves more than simply monetary remuneration and a progressive realisation that Spanish victims' needs are complex and extensive. This new approach is embodied in the 2008 Basque Law on Recognition and Reparation for Victims of Terrorism, the 2011 Act on Recognition and Comprehensive Protection for Victims of Terrorism and its 2013 Regulation implementing the Law. These measures all acknowledge the individual and public dimensions of victims' rights. They address not only the financial and medical but also the psychological, educational, housing and work life needs of the victims. In addition, the public spheres of victimhood revolving around notions of memory, dignity, truth and justice have and continue to receive growing recognition.

However the state has not been equally successful in addressing both categories of needs. Victims' have tended to perceive that their individual needs have been better met than their social ones. This maybe a reflection of the fact that their individual needs have been already met to certain degree and -given their tangible nature- can be more easily met. Yet, at the same time, it is also clear that some dimensions of their public needs are very challenging to address: for instance, the victims' right to dignity is affected by evidence of continuing public shows of support for ETA and their prisoners, mostly in towns of Basque Country governed by representatives of the Abertzale Left. Therefore, one can make the argument that some of these social needs cannot be fully addressed by state authorities alone. They would require the assimilation of these principles by the whole society (and not 'just' the vast majority of its members). 
As a result, some associations of victims have not only tried to provide psychological, administrative and legal help but still strive to ensure that victims receive social and political recognition. Victims groups are therefore not only a meeting place for people suffering from the same traumatic experience, a point of reference and a place of comfort, they are also centres of political activism aiming to influence government policy, to ensure for instance that government measures do not result in what they regard as impunity for imprisoned terrorists. It is now in this public arena where the next phase for the struggle for the rights of victims of terrorism is being fought.

\section{References}

Alonso, R., Domínguez, F. and García Rey, M. (2010) Vidas Rotas. Historia de los hombres, mujeres y niños víctimas de ETA (Madrid: Espasa Calpe).

BOE (1979) Real Decreto Ley 3/1979, de 26 de enero, sobre protección de la seguridad ciudadana. Boletín Oficial del Estado 28, 1 February 1979, 2636-2637. https://www.boe.es/buscar/doc.php?id=BOE-A-1979-3062 .

BOE (1984) Ley Orgánica 9/1984, de 26 de diciembre, contra la actuación de bandas armadas y elementos terroristas y de desarrollo del artículo 55.2 de la Constitución. Boletín Oficial del Estado 3, 3 January 1985, 43-48. http://www.congreso.es/constitucion/ficheros/leyes_espa/lo_009_1984.pdf . 
BOE (1992) Real Decreto 673/1992, de 19 de junio, por el que se regulan los resarcimientos por daños a víctimas de bandas armadas y elementos terroristas. Boletín Oficial del Estado 156, 30 June 1992, 22235 - 22238. https://www.boe.es/buscar/doc.php?id=BOE-A-1992$\underline{15284}$.

BOE (1992) Real Decreto 851/1992, de 10 de julio, por el que se regulan determinadas pensiones extraordinarias causadas por actos de terrorismo. Boletín Oficial del Estado 184, 1 August 1992, 26982 - 26985. http://www.boe.es/diario_boe/txt.php?id=BOE-A-1992$\underline{18325}$.

BOE (1995) Ley Orgánica 10/1995, de 23 de noviembre, del Código Penal. Boletín Oficial del Estado 281, 24 November 1995, 33987-34058.

http://www.boe.es/buscar/doc.php?id=BOE-A-1995-25444 .

BOE (1996) Ley 13/1996, de 30 de diciembre, de Medidas Fiscales, Administrativas y del Orden Social. Boletín Oficial del Estado 315, 31 December 1996, 38974 - 39064. http://www.boe.es/diario_boe/txt.php?id=BOE-A-1996-29117 .

BOE (1997) Real Decreto 1211/1997, de 18 de julio, por el que se aprueba el Reglamento de Ayudas y Resarcimientos a las víctimas de delitos de terrorismo. Boletín Oficial del Estado 
65, 17 March 2003, 10262 - 10273. https://www.boe.es/diario_boe/txt.php?id=BOE-A-2003$\underline{5455}$.

BOE (1999) Ley 32/1999, de 8 de octubre, de Solidaridad con las víctimas del terrorismo.

Boletín Oficial del Estado 242, 9 October 1999, 36050-36052.

https://www.boe.es/diario_boe/txt.php?id=BOE-A-1999-20063.

BOE (2003) Ley 2/2003, de 12 de marzo, de modificación de la Ley 32/1999, de 8 de octubre, de solidaridad con las víctimas del terrorismo. Boletín Oficial del Estado 62, 13 March 2003, 9763-9764. http://www.boe.es/buscar/doc.php?id=BOE-A-2003-5175 .

BOE (2010) Ley Orgánica 5/2010, de 22 de junio, por la que se modifica la Ley Orgánica 10/1995, de 23 de noviembre, del Código Penal. Boletín Oficial del Estado 152, 23 June 2010, 54811-54883. http://www.boe.es/boe/dias/2010/06/23/pdfs/BOE-A-2010-9953.pdf .

BOE (2011) Ley 29/2011, de 22 de septiembre, de Reconocimiento y Protección Integral a las Víctimas del Terrorismo. Boletín Oficial del Estado 229, 23 September 2011, 100566100592. https://www.boe.es/boe/dias/2011/09/23/pdfs/BOE-A-2011-15039.pdf .

BOE (2013) Real Decreto 671/2013, de 6 de septiembre, por el que se aprueba el Reglamento de la Ley 29/2011, de 22 de septiembre, de Reconocimiento y Protección 
Integral de las Víctimas del Terrorismo. Boletín Oficial del Estado 224, 18 September 2013, 72190-73112. http://www.boe.es/diario_boe/txt.php?id=BOE-A-2013-9680 .

BOE (2013) Real Decreto 233/2013, de 5 de abril, por el que se regula el Plan Estatal de fomento del alquiler de viviendas, la rehabilitación edificatoria, y la regeneración y renovación urbanas, 2013-2016. Boletín Oficial del Estado 86, 10 April 2013, 26623-26684. https://www.boe.es/diario_boe/txt.php?id=BOE-A-2013-3780 .

BOPV (1988) Decreto 221/1988, de 4 de agosto, por el que se aprueba el Programa de Ayudas a las víctimas del terrorismo. Boletín Oficial del País Vasco 163, 2 September 1988, 5292- 5297. http://www.lehendakaritza.ejgv.euskadi.net/r48bopv2/es/bopv2/datos/1988/09/8801980a.pdf .

BOPV (2002) Decreto 214/2002, de 24 de septiembre, por el que se regula el Programa de Ayudas a las Víctimas del Terrorismo. Boletín Oficial del País Vasco 185, 30 September 2002, 17560- 17578. http://www.lehendakaritza.ejgv.euskadi.net/r48bopv2/es/bopv2/datos/2002/09/0205497a.pdf .

BOPV (2008) Ley 4/2008, de 19 de junio, de Reconocimiento y Reparación a las Víctimas del Terrorismo. Boletín Oficial del País Vasco 124, 1 July 2008, 17308-17338. http://www.euskadi.net/bopv2/datos/2008/07/0804014a.pdf . 
BOPV (2010) Decreto 290/2010, de 9 de noviembre, de desarrollo del sistema de asistencia integral a las víctimas del terrorismo. Boletín Oficial del País Vasco 239, 15 December 2010, 61251-612528. http://www.euskadi.net/bopv2/datos/2010/12/1006125a.pdf .

Calleja, J.M. (2006) Algo habrá hecho: odio, miedo y muerte en Euskadi (Madrid: Espasa Calpe).

Funes, M.J. (1998) 'Social Responses to Political Violence in the Basque Country: Peace Movements and Their Audience', The Journal of Conflict Resolution, 42(4), 493-510.

FVT (2013) 'El Consejo de Ministros aprueba el Reglamento de Reconocimiento y Protección Integral de las Víctimas del Terrorismo', Revista de la Fundación de Víctimas del Terrorismo, 44, 22-25.

Martín Ríos, M. (2008) 'La reparación a las víctimas del delito por parte del Estado: análisis del caso español', Rivista di Criminologia, Vittimologia e Sicurezza , 2(3), 88-109.

Mir Puigpelat, O. (2000a) ‘Indemnizaciones a las víctimas del terrorismo’, InDret - Review on the Analysis of Law, 1/00, 1-10. 
Mir Puigpelat, O. (2000b) 'La Ley de solidaridad con las víctimas del terrorismo y su desarrollo reglamentario', Justicia Administrativa, 8, 25-44.

Lloveras , M-R. (2002) Indemnizaciones a las víctimas del terrorismo. Evolución normativa y aplicación jurisprudencial. InDret Working Paper 92 (Barcelona: Universitat Pompeu Fabra).

Martínez Gorriarán, C. (2008) Movimientos cívicos. De la calle al Parlamento (Madrid: Ediciones Turpial).

Pérez, K. (2003) Los derechos de las víctimas y su conquista (Bilbao: Asociación para la Defensa de la Dignidad Humana).

Pulgar, M.B. (2004) Víctimas del Terrorismo. 1968-2004 (Madrid: Dykinson).

Ramos, S. (2013) 'El Nuevo Reglamento y los Futuros Retos', Revista de la Fundación de Víctimas del Terrorismo, 44, 26-28.

Reinares, Fernando (2003) 'Democratization and State Responses to Protracted Terrorism in Spain' in M. van Leeuwen (ed.) Confronting Terrorism. European Experiences, Threat Perceptions and Policies (The Hague: Kluwer Law International). 
Rodríguez Uribes, J.M. (2011) ‘De los años de plomo al tiempo de los derechos', Revista de la Fundación de Víctimas del Terrorismo, 35, 56-57.

Sánchez-Cuenca, I. (2007) 'The Dynamics Of Nationalist Terrorism: ETA and the IRA', Terrorism and Political Violence, 19(3), 289-306.

Shabad, G. and Llera, F.J. (1995) 'Political Violence in a Democratic State: Basque Terrorism in Spain' in M. Crenshaw (ed.) Terrorism in Context (University Park, The Pennsylvania State University Press).

Varona, G. (2009) Atención institucional a las víctimas del terrorismo en Euskadi: informe extraordinario del Ararteko al Parlamento Vasco (Vitoria-Gasteiz: Ararteko).

\section{Notes}

\footnotetext{
${ }^{1}$ Asociación 11M Afectados del Terrorismo (http://www.asociacion11m.org/index.php) and Asociación de Ayuda a las Víctimas del 11-M (http://ayuda11m.org/) .

${ }^{2} 191$ people lost their lives and more than 1,800 were injured by the bombings. For an overview of the Madrid attacks and their aftermath see:

http://news.bbc.co.uk/1/shared/spl/hi/guides/457000/457031/html/default.stm
} 
${ }^{3}$ Laws for the assistance of victims have been passed by parliaments in the Autonomous Communities of Valencia, Extremadura, Aragón, Navarre, Madrid and Basque Country.

${ }^{4}$ See Article 3 of the 2011 Law of Recognition and Comprehensive Protection for Victims of Terrorism.

${ }^{5}$ See Article 4 of the abovementioned legislation.

${ }^{6}$ See: http://elpais.com/diario/2008/02/28/opinion/1204153204_850215.html

${ }^{7}$ Francisco José Alcaraz, the then President of the association, was a vociferous opponent of the Socialist government's counter-terror policy during this period. See:

http://www.elmundo.es/elmundo/2012/07/24/espana/1343123769.html

${ }^{8}$ See FVT Statutes at:

http://www.fundacionvt.org/images/fvt/pdfs/memoria/2012/4_estatutos.pdf

9 The latest (2012) FVT Annual report is available at:

http://www.fundacionvt.org/index.php?option=com_content\&task=category\&sectionid=6\&id $=84 \&$ Itemid $=184$

${ }^{10}$ See: http://www.elcorreo.com/alava/20140402/mas-actualidad/politica/interior-acuerda$\underline{\text { ubicar-vitoria-201404021647.html }}$

11 A Day of Memory to commemorate the victims of violence was instituted by the Parliament in 2010, although it has been marred by divisions between Basque political parties: http://www.elcorreo.com/vizcaya/rc/20131110/sociedad/camara-vasca-recuerdavictimas-201311101331.html

${ }^{12}$ Including, for instance, the 1982 Regulation of the abovementioned 1979 Law or the 1986 Regulation of the 1984 Law against the activities of armed groups and terrorist organisations. 
${ }^{13}$ The ceasefire was eventually broken by ETA in January 2000.

${ }^{14}$ These forms of reparation are strictly designed for the individual. As we will later see, public forms of recognition will not be regulated until the 2011 Law.

${ }^{15}$ The Declaración de Balmaseda is available at: http://www.acfsevt.es/?p=354

${ }^{16}$ For a summary of this position see:

http://www.eitb.com/es/noticias/politica/detalle/1331936/begona-urroz-eta--el-dril-matonina-no-eta-policia/

${ }^{17}$ The offence of 'glorification of terrorism' had been introduced through Article 578 in the 1995 revision of the Spanish Penal Code (BOE, 1995).

${ }^{18}$ See an example in: http://www.acfsevt.es/?p=4503. For a brief overview of the evolution of the legislation: http://www.europapress.es/murcia/noticia-gobierno-aprobara-mananareglamento-ley-victimas-terrorismo-ano-medio-retraso-20130905193444.html

${ }^{19}$ Article 5 of the 2011 Law only stated that these persons 'shall be subject of special attention by competent Public Administrations' without specifying the nature of such attention.

${ }^{20}$ The Abertzale Left is the network of pro-independence political actors who openly supported in the past ETA's armed struggle.

${ }^{21}$ See: http://www.abogacia.es/2014/02/21/el-gobierno-aprueba-el-proyecto-de-ley-dejusticia-gratuita/

${ }^{22}$ The first evaluation of the plan was carried out in 2008: http://www.euskadi.net/r332288/es/contenidos/informacion/paz_convivencia/es_paz_conv/adjuntos/plan_pazyconvivenc ia_evaluacion_20080114_es.pdf 
${ }^{23}$ This instrument was reformulated in 2010 into the Plan for Coexistence and Delegitimisation of Violence (2010/2011) : $\underline{\text { http://www.lehendakaritza.ejgv.euskadi.net/r48- }}$ rplancoo/es/contenidos/plan_programa_proyecto/plan_02/es_plan_02/plan_02.html

${ }^{24}$ The Council was finally set up in 2010: http://www.irekia.euskadi.net/es/news/1572$\underline{\text { constituido-consejo-vasco-participacion-las-victimas-del-terrorismo }}$

${ }^{25}$ See: http://www.avt.org/comunicados-y-noticias/presentado-el-primer-informe-del$\underline{\text { observatorio-contra-la-impunidad/643 }}$

${ }^{26}$ For an illustration, see the following Op-Ed by victims' representatives: http://www.diariovasco.com/pg060512/prensa/noticias/Opinion/200605/12/DVA-OPI$\underline{378 . h t m l}$

${ }^{27}$ Author's translation. 